\title{
Dopamine, behavior, and addiction
}

\author{
Roy A. Wise ${ }^{1,2^{*}}$ and Chloe J. Jordan ${ }^{3}$
}

\begin{abstract}
Addictive drugs are habit-forming. Addiction is a learned behavior; repeated exposure to addictive drugs can stamp in learning. Dopamine-depleted or dopamine-deleted animals have only unlearned reflexes; they lack learned seeking and learned avoidance. Burst-firing of dopamine neurons enables learning_long-term potentiation (LTP)—of search and avoidance responses. It sets the stage for learning that occurs between glutamatergic sensory inputs and GABAergic motor-related outputs of the striatum; this learning establishes the ability to search and avoid. Independent of burst-firing, the rate of single-spiking — or "pacemaker firing" — of dopaminergic neurons mediates motivational arousal. Motivational arousal increases during need states and its level determines the responsiveness of the animal to established predictive stimuli. Addictive drugs, while usually not serving as an external stimulus, have varying abilities to activate the dopamine system; the comparative abilities of different addictive drugs to facilitate LTP is something that might be studied in the future.
\end{abstract}

Keywords: Dopamine, Behavior, Addiction

\section{Background}

Addictive drugs are habit-forming. Here we use the phase "habit-forming broadly [1] to refer to the entire progression toward the stimulus-response end habits [2] discussed in the specialist literature.Rewards are habitforming because predictive stimuli-reward-predictors as well as punishment-predictors-come to cause dopaminergic burst-firing, and burst-firing enhances or enables the separate development of long-term potentiation (LTP) and long-term depression (LTD) of learned connections between other systems: glutamatergic input pathways and GABAergic output pathways [3]. The primary source of these is in the striatum; the striatum receives sensory inputs from the cortex and sends motorrelated outputs that are essential for food-searching and punishment-avoidance. The primary evidence for dopaminergic involvement in reward-driven learning comes from studies of genetically altered mice that cannot synthesize dopamine in the brain. These mice appear normal

*Correspondence: rwise@intra.nida.nih.gov

${ }^{1}$ Intramural Research Program, National Institute on Drug Abuse, 250 Mason Lord Drive, Baltimore, MD, USA

Full list of author information is available at the end of the article when born, but they fail to learn food-seeking and, after weaning, die of starvation unless they are force-fed [4]. Such animals have only unconditioned reflexes"consummatory" reflexes [5] - and, having not learned to feed,-an "appetitive" response [5] -also fail to learn to seek or avoid other rewards. That dopamine is critical for such learning is evident from the dopaminergic recordings of Schultz and colleagues [6, 7] and from recent optogenetic studies that confirm dopaminergic activation as rewarding [8-11].

\section{Dopamine-deficient animals}

Dopamine-deficient animals are born with minimallearned in utero-knowledge of the environment. These animals have normal reflexes: they can swallow food if it is placed in their mouth [12] and they escape from aversive stimuli [13-15]. They do not, however, learn to search for rewards or avoid aversive stimuli $[4,16]$. They must learn to approach the environmental cues that guide behavior, leading to food and other rewards [17, $18]$, just as they must learn to avoid predictive stimuli that warn of punishers. Learned approach to rewards is an appetitive behavior and is essential for addiction as well as for feeding; indeed, the strongest evidence of original author(s) and the source, provide a link to the Creative Commons licence, and indicate if changes were made. The images or other third party material in this article are included in the article's Creative Commons licence, unless indicated otherwise in a credit line to the material. If material is not included in the article's Creative Commons licence and your intended use is not permitted by statutory regulation or exceeds the permitted use, you will need to obtain permission directly from the copyright holder. To view a copy of this licence, visit http://creativecommons.org/licenses/by/4.0/. The Creative Commons Public Domain Dedication waiver (http://creativeco mmons.org/publicdomain/zero/1.0/) applies to the data made available in this article, unless otherwise stated in a credit line to the data. 
drug self-administration involved responses to predictors because the animals, in these cases, rarely have sensory contact with the drug itself [19].

Dopaminergic burst-firing enables environmental learning Genetically modified neonates that cannot synthesize dopamine in the brain [4], like adult animals with their dopamine systems lesioned [16] or blocked pharmacologically [20-22] -dopamine challenged animals-fail to find and eat external foods [20,22] and fail to seek and consume addictive drugs [3, 23-25] or other rewards [21, $26,27]$.

The dopamine system is activated by three kinds of external stimuli: rewarding stimuli, punishing stimuli, and novel stimuli. When activated by rewards or punishers, portions of the dopamine system discharge in bursts [6, 28-32], whereas other portions are inhibited [33-35]. Dopaminergic burst discharges involve two or more linked spikes with progressively decreasing amplitude and short inter-discharge intervals (about $60 \mathrm{~ms}$ between the first and second discharge and about $120 \mathrm{~ms}$ between subsequent discharges) [36]. These discharges cause very local accumulations of dopamine in the striatum, at local peaks of $100 \mathrm{nM}$ or greater concentration, as measured by fast-scan cyclic voltammetry (FSCV) [37].

The primary sensory inputs to the dopamine systemdriving this release-are glutamatergic and perhaps cholinergic terminals from cell bodies of the latero-dorsal and pedunculopontine tegmental nuclei [38, 39]; similar burst firing can be activated as well by direct glutamatergic stimulation of dopaminergic neurons in isolated brain slices [40]. In dopamine-intact animals, dopaminergic neurons burst-fire in response not just to rewards or punishers but also to stimuli that reliably precede-and thus predict-rewards and punishers $[6,7,41]$.

The burst-firing in response to predictors of rewards or punishers develops with age, as the animal learns about the environment. The burst-responses should not really be seen as travelling from the unconditioned rewards and punishers to their predictors; rather, the process of burst-firing develops anew in response to predictors that involve a Hebbian mechanism [42, 43]. Hebb has postulated a mechanism by which repeated synaptic input from a (predictor) cell that reliably precedes another (reward) neuron becomes linked to its target. As responses to predictors develop, the burst-responding in response to the actual rewards or punishers is temporarily lost; responsiveness, however-in this case inhibition of firing-appears when the reward or punisher fails to appear at the expected time [44]. When burstfiring develops in response to reward-predictors it enables cellular learning in surrounding synapses; these are
glutamate-GABA synapses localized within microns of the sites of dopamine release.

Burst-firing of the dopamine system is only a first step in the learning; the formation of the synapses for searching develops in other cellular elements. Dopamine bursting enables development of long-term potentiation (LTP) and long-term depression (LTD), and, in the striatum, this occurs between glutamatergic sensory inputs and GABAergic motor-related outputs [45, 46]. Dopamine in the striatum reaches and binds to high-affinity D2 dopamine receptors and low-affinity D1 receptors $[48,49]$. At high affinity D2 receptors significant binding occurs, making D2 receptors particularly sensitive to phasic decreases in dopamine release. At low affinity D1 receptors less dopamine should be bound, making D1 receptors particularly sensitive to phasic increases in dopamine release. Movements result when D1 receptors are activated and inhibition of movement results when D2 receptors are activated [9]. In behaving animals, activation of D1 and D2 are momentary complements; their activations occur concurrently [50]. Concurrent activation presumably involves activating one subset of muscles (D1) to do something while inhibiting (D2) other sets of muscles, antagonistic muscles, that would normally interfere with the elicited action. The reward-predicting stimuli that lead an animal to anticipate rewards-both natural rewards and drug rewards-are established by this kind of learning $[3,25]$.

\section{Dopaminergic pacemaker-firing modulates motivation}

Whereas burst responding of the dopamine system is elicited by external stimuli, dopaminergic single discharges also spontaneously occur; these discharges are identified as pacemaker firing because they result from a depolarizing current within the dopaminergic cells themselves [51]. Such discharges can be seen in brain slice preparations even when, in vitro, excitatory inputs have been eliminated [40]. Pacemaker firing is slower than burst firing; it occurs at about half the frequency of burstfiring [51]. The rate of pacemaker firing is modulated by two sources: by increases or decreases of inhibitory inputs from GABA-containing cells [52] and by hormones and peptides that act at receptors on dopaminergic neurons themselves [53-55] or that act through their inputs [55-57]. The tonic modulation of the dopamine system-pacemaker firing, supplemented by episodes of burst-firing-is a correlate of, presumably a cause of, motivational arousal.

Motivational arousal is a state variable; it regulates readiness to respond to external stimuli. While rewards and punishers elicit responses regardless of emotional state, it is predictors of rewards or punishers that depend on motivational arousal. In resting animals, 
it is pacemaker firing that varies as a function of internal state and determines when, and to what degree, the animal responds to reward-predictors. Burst-firing can also influence motivational arousal; consider the behavior of an animal when a pheromone-emitting conspecific passes nearby. Motivational arousal varies over time and, in resting animals, determines when a previously sated animal starts to become hungry and interested in seeking food.

In a resting animal, the release of dopamine is detected historically by microdialysis [58]. Baseline levels of dopamine are estimated to be around $5 \mathrm{nM}[59,60]$; microdialysis can measure dopamine levels this low and much lower; microdialysis-in tetrodotoxin-treated animalscan measure dopamine at $1 \%$ of baseline levels [61]. However, microdialysis is an insensitive measure, averaging rather than giving data from single cells; it involves the sampling of extracellular fluids through large $(\sim 250$ microns) push-pull cannulae in the brain, in contact with many dopamine terminals, and it usually gives averages taken over minutes or tens of minutes. One possibility is that basal dopamine levels are near $5 \mathrm{nM}$ at all points throughout the striatum; alternatively, it is possible that microdialysis simply reflects the average of large fluctuations around some unknown actual baseline level. In contrast, however, the alternative-FSCV, for examplemeasures individual elevations and does not have the sensitivity to detect the low levels of dopamine in resting animals; it is insensitive to dopamine at concentrations below $20 \mathrm{nM}$ [37] and uses "background subtraction" to isolate dopamine fluctuations from noise [62]. FSCV measures peak concentrations that are isolated both in localization and in time. Because the degree of temporal and spatial heterogeneity is not known, it is not clear the degree to which these isolated dopamine peaks contribute to the motivational arousal in active animals. More recently developed techniques involving optical technology, calcium imaging, and genetically-encoded fluorescent protein sensors [63] will give us better methods for assessing pacemaker dopamine discharge.

The evidence implicating a causal role of dopamine in motivational function comes from experiments where the dopamine system has been experimentally manipulated [25]. These include the following: Animals with partial dopamine depletion show reduced energy in learned tasks [64]. Parkinsonian patients with decreased dopamine levels have deficits in speed of hand movements [65] and in willingness to squeeze a dynamometer [66]; when dopamine is replaced by L-DOPA administration, these symptoms decrease [66]. Amphetamine, which augments dopamine release, causes humans to increase effort for monetary rewards [67]. A dopamine uptake inhibitor that doubles baseline dopamine levels increases willingness to work for high-carbohydrate pellets [68]. Restoring dopamine by re-establishing synthesis in dopaminergic neurons restores locomotion and food-seeking in dopamine-deficient mice $[69,70]$.

The fact that dopamine-depleted animals already have responses to rewards and punishers allows a stronger definition of motivation than has been offered in the past; the level of motivation varies with responsiveness to predictive stimuli in the environment. The distinction here is between predictive stimuli that lead toward or away from rewards or punishers and rewarding and punishing stimuli themselves, to which dopamine-depleted animals continue to respond.

Motivation is not a linear function of dopamine levels and may vary with noradrenergic as well as dopaminergic motivation. Motivation is low when dopamine levels are low, and it increases as dopamine levels start to increase. However, when dopamine levels are doubled or tripledsuch levels as are induced by self-administered doses of amphetamine [71], cocaine [72], or opiates [73] - motivation is lost [74]. Thus the relation that links dopamine level with motivation appears to be a classic "U"-shaped function; such functions have traditionally been associated with arousal and motivation $[75,76]$.

\section{Predictive cues can become aversive}

Wheeler and colleagues have suggested conditions in which cocaine-predictive cues can become associated with negative affect [77-79]. The first of these papers discussed "cocaine predictive" cues, but the second paper more correctly characterized them as cues of "delayed cocaine delivery." The parameters of establishing the association of a sweet-tasting substance with aversive conditioning are of particular interest, in part because people who use addictive drugs sometimes appear to do so in anticipation of, or in fear of, expected aversive symptoms.

In the Wheeler studies, animals were given series of 30 or 45 min-long, intra-oral taste stimuli that preceded $2 \mathrm{~h}$ sessions of intravenous saline or cocaine self-administration. After several days of training the facial expression elicited by the taste cues [77] and the effect of these cues on dopamine release [78] were determined. A taste cue that preceded subsequent saline self-administration caused licking and lateral tongue movements-these are responses driven by sweet solutions-whereas cues that predicted delayed cocaine self-administration had come to cause gagging and gaping-the responses to aversive quinine solutions-[77]. Moreover, the cue predicting saline self-administration increased dopamine release, whereas the cue predicting cocaine self-administration inhibited dopamine release [77]. The critical factor here is that it was the predictor of delayed cocaine availability 
that became aversive. Delayed cocaine availability is not well associated with dopamine release; dopamine release is directly controlled by what happens in seconds after the prediction [44]. The immediate consequencefor the dopamine system-of the cue that predicted delayed cocaine was the absence of dopamine it caused after training with series of 29 or 44 one-minute cue exposures.

\section{Dopamine and addictive drugs}

Roles for dopamine in reward theory [80-82] and a role of reward in addiction [83] were established shortly after dopamine was established as a neurotransmitter. Dopamine was first identified with reward function from anatomical [84] and pharmacological evidence [85-89]; it was subsequently implicated as well in motivational function [90-92]. Dopamine has broadly been associated with the rewarding effects of addictive drugs, particularly in the process of establishing habitual drug intake [24, 93, 94]. However, dopamine plays strongly established roles in the addictive properties of some drugs but is implicated by minimal evidence in others.

Amphetamine and cocaine The role of dopamine in the rewarding effects of the psychomotor stimulantsamphetamine and cocaine-are strongly established. Self-administered doses of amphetamine [71] or cocaine [72] elevate dopamine levels over four-fold. Dopamine antagonists at high doses block amphetamine and cocaine self-administration $[86,95,96]$. At low doses the antagonists cause compensatory increases in responding, suggesting that the rewarding effects of the stimulants has been attenuated [86, 95, 96]. Dopamine-selective lesions cause immediate loss of cocaine self-administration when the lesions are complete [97] and temporary loss when they are incomplete [98]. These lesioned animals continue to lever-press for the direct dopamine agonist, apomorphine, following these lesions, confirming that the lesioned animals remember their training history and have normal motor capacity [97, 98]. Finally, cocaine and amphetamine induces long-term synaptic changes in glutamate-GABA synapses in the striatum [99-101].

Opiates Heroin self-administration is also clearly dopamine-dependent. It more than triples resting dopamine levels [73], and while the role of dopamine in opiate addiction has been questioned [102], evidence from intravenous heroin self-administration studies makes it clear that animals usually request additional heroin each time their dopamine levels fall below about twice-normal levels [103]. An important possibility in experiments blocking opiate self-administration with dopamine antagonists is that the antagonists act not only at post-synaptic receptors but also at dopamine autoreceptors [104] where they increase dopamine firing and dopamine release. By increasing dopamine release-as heroin alone does not-dopamine antagonists elevate extracellular dopamine at the nerve terminal, desensitizing the system to the antagonist and, in this case, requiring more heroin to be effective. In any case, dopamine antagonists do block opiate self-administration [102]; the lack of compensatory increases in responding for heroin following low doses of dopamine antagonists [102] does not [105] rule out a role for dopamine in opiate reward. Studies of opiate-conditioned place preferences adds to the evidence that opiates are habit-forming-place-preferences address the first element of search-habits, the locomotion to the place where drugs are available-and that their habitforming effects are blocked by dopamine antagonists $[106,107]$.

Nicotine Self-administration of nicotine also appears to be dopamine-dependent. Nicotine self-administration causes burst-firing of dopaminergic neurons $[108,109]$ and elevates dopamine levels to $150-200 \%$ of baseline [110]. It is disrupted by selective dopaminergic antagonists [111] and selective neurochemical lesions [112]. Nicotine acts at sites and on receptors expressed by dopamine neurons and inhibitory controllers of dopamine neurons, such as local GABAergic cells within the ventral tegmental area (VTA). Deletion of nicotinic receptor subunits, such as $\beta 2$, abolishes nicotine-induced dopamine release and attenuates nicotine self-administration, and re-expression of $\beta 2$ restores nicotine's rewarding effects [113-115]. Nicotine causes conditioned place preferences; this is blocked with dopamine antagonists [116]. Nicotine enables LTP in glutamatergic inputs to the dopamine system and primes the ability of cocaine to induce LTP in the amygdala $[117,118]$, a structure anatomically related to the striatum [119].

Ethanol The evidence that dopamine is important for the rewarding effects of ethanol is also substantial but weaker than that supporting dopamine involvement in stimulant or opiate reward. Part of the problem is that we still have no animal model of self-administration that is sufficient to maintain intoxication [120]; rats can be induced to drink alcohol [121-124], and animals can be made physically dependent on alcohol $[125,126]$, however, even in already dependent rats, voluntary self-administration that maintains dependence is not seen. Ethanol (and ethanol withdrawal) increases burstfiring in dopaminergic animals [127, 128]; ethanol also increases pacemaker dopaminergic firing [129]. Ethanol can increase dopamine levels to $150-200 \%$ of baseline [94], and increases dopamine cell burst-firing as well as pacemaker-like firing in the VTA; note, however, that a subset of VTA dopamine neurons are instead inhibited by ethanol [128] and this might also be important. 
Dopamine antagonists decrease lever-pressing for ethanol in a sucrose-fading procedure [130, 131]; this is done in animals that were experienced with ethanol and during intervals of alcohol deprivation. However, the case of alcohol is unusual. In a conditioned place preference study, alcohol is reported to be dopamine-dependent in alcohol-naive animals but not in withdrawn, experienced, animals [132]. One possibility is that a dopamine-independent pathway is also involved in ethanol reinforcement $[132,133]$. Ethanol enhances synaptic plasticity in the striatum [101].

Cannabis There are many cannabinoids, some of which have psychoactive effects and remain to be studied. The primary psychoactive ingredient in marijuana is ${ }^{\Delta 9}$-tetrahydrocannabinol (THC). While some studies have reported that this agent is self-administered intravenously by rodents [134] and non-human primates [135] and increases striatal dopamine levels [136-139], other studies suggest that THC is not very rewarding in other animals, such that THC self-administration is modest and difficult to sustain [140,141]. Newer rodent models of edible or vaporized THC self-administration hold promise [142, 143]. However, species differences in cannabinoid receptor expression and distribution, particularly in the VTA, may underlie differences in the rewarding effects of THC between humans, non-human primates and rodents [144].

THC is an unusual agent; two of its endogenous analogues-anandamide, 2-arachidonylglycerol-are expressed by dopaminergic (and other) neurons and are released when dopaminergic neurons fire; they influence dopamine turnover through actions on inputs to the dopamine system $[145,146]$. THC is self-administered into two dopamine-rich regions, the posterior VTA where mesolimbic dopamine cell bodies are found and the posterior ventral striatum, where terminals of that system terminate [147]; these sites of action implicate THC's actions on the dopamine system in reward function and the use of central drug self-administration suggests that site-specificity is important here.

Barbiturates and benzodiazepines Much less is known about self-administered doses of barbiturates or benzodiazepines. Barbiturates [148, 149] and benzodiazepines $[150,151]$ are self-administered both intravenously and intracranially into the VTA $[152,153]$ by animals. Benzodiazepines increase VTA dopamine neuron firing and induce LTP in glutamatergic inputs to VTA dopamine neurons through positive modulation of local $\mathrm{GABA}_{\mathrm{A}}$ receptors [154-157]. At experimenter-selected doses they elevate dopamine levels [158-161] and it has been suggested that they are addictive for this reason [24].

Caffeine Caffeine is self-administered by animals [148, $162,163]$ and produces conditioned flavor preferences (low doses) or conditioned place aversions (high doses) in rats when injected intraperitoneally or directly into the VTA [164]. A dopamine antagonist injected into the shell of the ventral striatum blocks these place preferences, whereas the antagonist injected into the core of the ventral striatum blocks the conditioned aversive effects [165]. Volatized, inhaled caffeine increases extracellular dopamine levels in the nucleus accumbens shell [166]. The mechanism by which caffeine does so is not clear. The main actions of caffeine are mediated through actions at adenosine receptors that form heteromers with dopamine receptors. However, in human Positron Emission Tomography (PET) studies, caffeine increases D2/D3 receptor availability in the ventral striatum, suggesting caffeine alone does not directly increase dopamine levels in this region [167]. Other studies suggest that caffeine enhances the rewarding effects of other manipulations, such as exercise [168] or ethanol consumption $[65,169]$.

\section{Conclusions}

Learned behavior-perhaps all or almost-all learned behavior-depends on dopamine function; dopamine deficient animals fail to learn to search for food or other rewards and fail to learn to avoid predictable punishers. Dopamine neurons discharge in bursts when triggered by external stimuli, and this burst-firing enables formation of potentiated glutamate-GABA signaling that is critical for learned searching. Dopamine neurons also discharge in slower single-impulse pacemaker firing and the rate of this firing appears to determine motivation in resting (inanimate) animals. The ability of addictive drugs to cause burst-like discharges in the dopamine system is the broadly assumed correlate of addiction, but the direct evidence for this assumption is linked strongly to amphetamine, cocaine, and opiates; the evidence is weaker for nicotine and alcohol, cannabis, barbiturates, benzodiazepines, and caffeine. The abilities of different addictive drugs to enable long-term potentiation and facilitate habit formation via dopaminergic mechanisms should be compared in future studies.

\section{Acknowledgements \\ Not applicable.}

\section{Authors' contributions}

RAW and CJJ each read the cited articles, planned the review, wrote the review, responded to reviewer comments, and modified the references for citation style. All authors read and approved the final manuscript.

\section{Funding}

Not applicable.

Availability of data and materials Not applicable. 


\section{Declarations}

Ethics approval and consent to participate Not applicable.

\section{Consent for publication}

Not applicable.

\section{Competing interests}

The authors declare that they have no competing interests.

\section{Author details}

${ }^{1}$ Intramural Research Program, National Institute on Drug Abuse, 250 Mason Lord Drive, Baltimore, MD, USA. ${ }^{2}$ Behavior Genetics Laboratory, McLean Hospital, Harvard Medical School, 115 Mill Street, Belmont, MA 02478, USA. ${ }^{3}$ Division of Alcohol, Drugs and Addiction, Department of Psychiatry, Harvard Medical School, McLean Hospital, 115 Mill Street, Belmont, MA 02478, USA.

Received: 11 May 2021 Accepted: 19 November 2021

Published online: 02 December 2021

\section{References}

1. Singer BF, Fadanelli M, Kawa AB, Robinson TE. Are cocaine-seeking "habits" necessary for the development of addiction-like behavior in rats? J Neurosci. 2018;38(1):60-73.

2. Balleine BW, Dickinson A. Goal-directed instrumental action: contingency and incentive learning and their cortical substrates. Neuropharmacology. 1998;37(4-5):407-19.

3. Wise RA. Dopamine, learning and motivation. Nat Rev Neurosci. 2004;5:483-94.

4. Palmiter RD. Dopamine signaling in the dorsal striatum is essential for motivated behaviors: lessons from dopamine-deficient mice. Ann NY Acad Sci. 2008;1129:35-46.

5. Craig W. Appetites and aversions as constituents of instincts. Biol Bull. 1918;34:91-107.

6. Ljungberg T, Apicella P, Schultz W. Responses of monkey dopamine neurons during learning of behavioral reactions. J Neurophysiol. 1992;67:145-63.

7. Schultz W, Apicella P, Ljungberg T. Responses of monkey dopamine neurons to reward and conditioned stimuli during successive steps of learning a delayed response task. J Neurosci. 1993;13:900-13.

8. Witten IB, Steinberg EE, Lee SY, Davidson TJ, Zalocusky KA, Brodsky M, et al. Recombinase-driver rat lines: tools, techniques, and optogenetic application to dopamine-mediated reinforcement. Neuron. 2011;72:721-33

9. Kravitz AV, Tye LD, Kreitzer AC. Distinct roles for direct and indirect pathway striatal neurons in reinforcement. Nat Neurosci. 2012;15(6):816-8.

10. Ilango A, Kesner AJ, Keller KL, Stuber GD, Bonci A, Ikemoto S. Similar roles of substantia nigra and ventral tegmental dopamine neurons in reward and aversion. J Neurosci. 2014;34(3):817-22.

11. Steinberg EE, Boivin JR, Saunders BT, Witten IB, Deisseroth $K$, Janak $\mathrm{PH}$. Positive reinforcement mediated by midbrain dopamine neurons requires D1 and D2 receptor activation in the nucleus accumbens. PLoS ONE. 2014;9(4):e94771.

12. Zhou QY, Palmiter RD. Dopamine-deficient mice are severely hypoactive, adipsic, and aphagic. Cell. 1995;83(7):1197-209.

13. Cooper BR, Breese GR, Grant LD, Howard JL. Effects of 6-hydroxydopamine treatments on active avoidance responding: evidence for involvement of brain dopamine. J Pharmacol Exp Ther. 1973;185(2):358-70.

14. Fibiger HC, Phillips AG, Zis AP. Deficits in instrumental responding after 6-hydroxydopamine lesions of the nigro-neostriatal dopaminergic projection. Pharmacol Biochem Behav. 1974;2(1):87-96.

15. Barbano MF, Wang HL, Zhang S, Miranda-Barrientos J, Estrin DJ, Figueroa-González A, et al. VTA glutamatergic neurons mediate innate defensive behaviors. Neuron. 2020;107(2):368-82.e8.

16. Ungerstedt U. Adipsia and aphagia after 6-hydroxydopamine induced degeneration of the nigro-striatal dopamine system. Acta Physiol Scand. 1971:367:95-122
17. Bindra D. Neuropsychological interpretation of the effects of drive and incentive-motivation on general activity and instrumental behavior. Psychol Rev. 1968;75:1-22

18. Bolles RC. Reinforcement, expectancy, and learning. Psychol Rev. 1972:79:394-409.

19. Wise RA. Brain reward circuitry: Insights from unsensed incentives. Neuron. 2002:36:229-40.

20. Wise RA, Spindler J, deWit H, Gerber GJ. Neuroleptic-induced "anhedonia" in rats: pimozide blocks reward quality of food. Science. 1978;201(4352):262-4.

21. Gerber GJ, Sing J, Wise RA. Pimozide attenuates lever pressing for water reinforcement in rats. Pharmacol Biochem Behav. 1981;14(2):201-5.

22. Wise RA, Schwartz HV. Pimozide attenuates acquisition of lever pressing for food in rats. Pharmacol Biochem Behav. 1981;15:655-6.

23. Wise RA. Neuroleptics and operant behavior: the anhedonia hypothesis. Behav Brain Sci. 1982;5:39-87.

24. Wise RA, Bozarth MA. A psychomotor stimulant theory of addiction. Psychol Rev. 1987;94(4):469-92.

25. Wise RA, Robble MA. Dopamine and addiction. Ann Rev Psychol. 2020;71:79-106.

26. Robinson DL, Phillips PE, Budygin EA, Trafton BJ, Garris PA, Wightman RM. Sub-second changes in accumbal dopamine during sexual behavior in male rats. NeuroReport. 2001;12(11):2549-52.

27. El-Guebaly N, Mudry T, Zohar J, Tavares H, Potenza MN. Compulsive features in behavioural addictions: the case of pathological gambling Addiction (Abingdon, England). 2012;107(10):1726-34.

28. Strecker RE, Jacobs BL. Substantia nigra dopaminergic unit activity in behaving cats: effect of arousal on spontaneous discharge and sensory evoked activity. Brain Res. 1985;361(1-2):339-50.

29. Schultz W. Responses of midbrain dopamine neurons to behavioral trigger stimuli in the monkey. J Neurophysiol. 1986;56:1439-61.

30. Horvitz JC, Stewart T, Jacobs BL. Burst activity of ventral tegmental dopamine neurons is elicited by sensory stimuli in the awake cat. Brain Res. 1997;759(2):251-8.

31. Brischoux F, Chakraborty S, Brierley DI, Ungless MA. Phasic excitation of dopamine neurons in ventral VTA by noxious stimuli. PNAS. 2009;106(12):4894-9.

32. Matsumoto M, Hikosaka O. Two types of dopamine neuron distinctly convey positive and negative motivational signals. Nature. 2009;459(7248):837-41.

33. Matsumoto H, Tian J, Uchida N, Watabe-Uchida M. Midbrain dopamine neurons signal aversion in a reward-context-dependent manner. eLife. 2016;5.

34. Juarez B, Han MH. Diversity of dopaminergic neural circuits in response to drug exposure. Neuropsychopharmacology. 2016;41(10):2424-46.

35. Verharen JPH, Luijendijk MCM, Vanderschuren L, Adan RAH. Dopaminergic contributions to behavioral control under threat of punishment in rats. Psychopharmacology. 2020;237(6):1769-82.

36. Grace AA, Bunney BS. The control of firing pattern in nigral dopamine neurons: burst firing. J Neurosci. 1984;4:2877-90.

37. Owesson-White CA, Roitman MF, Sombers LA, Belle AM, Keithley $R B$, Peele $J$, et al. Sources contributing to the average extracellular concentration of dopamine in the nucleus accumbens. J Neurochem. 2012;121(2):252-62

38. Floresco SB, West AR, Ash B, Moore H, Grace AA. Afferent modulation of dopamine neuron firing differentially regulates tonic and phasic dopamine transmission. Nat Neurosci. 2003;6(9):968-73.

39. Lodge DJ, Grace AA. The laterodorsal tegmentum is essential for burst firing of ventral tegmental area dopamine neurons. PNAS. 2006;103(13):5167-72.

40. Grace AA, Onn SP. Morphology and electrophysiological properties of immunocytochemically identified rat dopamine neurons recorded in vitro. J Neurosci. 1989;9(10):3463-81.

41. Kim KM, Baratta MV, Yang A, Lee D, Boyden ES, Fiorillo CD. Optogenetic mimicry of the transient activation of dopamine neurons by natural reward is sufficient for operant reinforcement. PLOS ONE. 2012;7(4):e33612.

42. Hebb DO. The organization of behavior. New York: Wiley; 1949.

43. Hebb DO. Essay on mind. New York: Erlbaum; 1980.

44. Schultz W, Dayan P, Montague PR. A neural substrate of prediction and reward. Science. 1997:275:1593-9. 
45. Centonze D, Picconi B, Gubellini P, Bernardi G, Calabresi P. Dopaminergic control of synaptic plasticity in the dorsal striatum. Eur J Neurosci. 2001;13:1071-7.

46. Calabresi P, Picconi B, Tozzi A, Di Filippo M. Dopamine-mediated regulation of corticostriatal synaptic plasticity. Trends Neurosci. 2007;30(5):211-9.

47. Surmeier DJ, Ding J, Day M, Wang Z, Shen W. D1 and D2 dopaminereceptor modulation of striatal glutamatergic signaling in striatal medium spiny neurons. Trends Neurosci. 2007;30(5):228-35.

48. Richfield EK, Penney JB, Young AB. Anatomical and affinity state comparisons between dopamine $D 1$ and $D 2$ receptors in the rat central nervous system. Neuroscience. 1989;30(3):767-77.

49. Neve KA, Neve RL. Molcular biology of dopamine receptors. In: Neve KA, Neve RL, editors. The dopamine receptors. Totowa: Humana Press; 1997. p. 27-76.

50. Cui G, Jun SB, Jin X, Pham MD, Vogel SS, Lovinger DM, et al. Concurrent activation of striatal direct and indirect pathways during action initiation. Nature. 2013:494(7436):238-42.

51. Grace AA, Bunney BS. The control of firing pattern in nigral dopamine neurons: single spike firing. J Neurosci. 1984;4(11):2866-76.

52. Grace AA. The regulation of dopamine neuron activity as determine by in vivo and in vitro intracellular recordings. In: Chiodo LA, Freeman A, editors. Neurophysiology of dopaminergic systems: current status and Clinical perspectives. Detroit: Lakeshor Publishing; 1987. p. 1-66.

53. Figlewicz DP, Evans SB, Murphy J, Hoen M, Baskin DG. Expression of receptors for insulin and leptin in the ventral tegmental area/substantia nigra (VTA/SN) of the rat. Brain Res. 2003;964(1):107-15.

54. Fulton S, Pissios P, Manchon RP, Stiles L, Frank L, Pothos EN, et al. Leptin regulation of the mesoaccumbens dopamine pathway. Neuron. 2006;51(6):811-22.

55. Jerlhag E, Egecioglu E, Dickson SL, Engel JA. Glutamatergic regulation of ghrelin-induced activation of the mesolimbic dopamine system. Addiction Biol. 2011;16(1):82-91.

56. Leinninger GM, Jo YH, Leshan RL, Louis GW, Yang H, Barrera JG, et al. Leptin acts via leptin receptor-expressing lateral hypothalamic neurons to modulate the mesolimbic dopamine system and suppress feeding. Cell Metab. 2009;10(2):89-98.

57. Mietlicki-Baase EG, Ortinski PI, Rupprecht LE, Olivos DR, Alhadeff AL, Pierce RC, et al. The food intake-suppressive effects of glucagon-like peptide-1 receptor signaling in the ventral tegmental area are mediated by AMPA/kainate receptors. Amer J Physiol Endocrinol Metab. 2013;305(11):E1367-74.

58. Tossman U, Ungerstedt U. Microdialysis in the study of extracellular levels of amino acids in the rat brain. Acta Physiol Scand. 1986;128(1):9-14.

59. Parsons $\mathrm{LH}$, Justice JB. Extracellular concentration and in vivo recovery of dopamine in the nucleus accumbens using microdialysis. J Neurochem. 1992:58:212-8.

60. Sam PM, Justice JB Jr. Effect of general microdialysis-induced depletion on extracellular dopamine. Anal Chem. 1996;68(5):724-8.

61. Westerink BHC, Tuntler J, Damsma G, Rollema H, De Vries JB. The use of tetrodotoxin for the characterization of drug-enhanced dopamine release in conscious rats studied by brain dialysis. Naunyn-Schmiedeberg's Arch Pharmacol. 1987:336:502-7.

62. Howell JO, Kuhr WG, Ensman RE, Wightman RM. Background subtraction for rapid scan voltammetry. J Electroanalytical Chem Interfacial Electrochem. 1986;209:77-90.

63. Yocky AG, Covey DP. Evolution of in vivo dopamine monitoring techniques. Pharmacol Biochem Behav. 2021;200:173078.

64. Salamone JD, Correa M, Farrar A, Mingote SM. Effort-related functions of nucleus accumbens dopamine and associated forebrain circuits. Psychopharmacology. 2007;191(3):461-82.

65. Mazzoni P, Hristova A, Krakauer JW. Why don't we move faster? Parkinson's disease, movement vigor, and implicit motivation. J Neurosci. 2007;27(27):7105-16.

66. Chong TT, Bonnelle V, Manohar S, Veromann KR, Muhammed K, Tofaris GK, et al. Dopamine enhances willingness to exert effort for reward in Parkinson's disease. Cortex. 2015;69:40-6.

67. Wardle MC, Treadway MT, Mayo LM, Zald DH, de Wit H. Amping up effort: effects of d-amphetamine on human effort-based decisionmaking. J Neurosci. 2011;31(46):16597-602.
68. Yohn SE, Errante EE, Rosenbloom-Snow A, Somerville M, Rowland M, Tokarski K, et al. Blockade of uptake for dopamine, but not norepinephrine or 5-HT, increases selection of high effort instrumental activity: implications for treatment of effort-related motivational symptoms in psychopathology. Neuropharmacol. 2016;109:270-80.

69. Szczypka MS, Mandel RJ, Donahue BA, Snyder RO, Leff SE, Palmiter RD. Viral gene delivery selectively restores feeding and prevents lethality of dopamine-deficient mice. Neuron. 1999;22(1):167-78.

70. Heusner CL, Hnasko TS, Szczypka MS, Liu Y, During MJ, Palmiter RD. Viral restoration of dopamine to the nucleus accumbens is sufficient to induce a locomotor response to amphetamine. Brain Res. 2003;980(2):266-74.

71. Ranaldi R, Pocock D, Zereik R, Wise RA. Dopamine fluctuations in the nucleus accumbens during maintenance, extinction, and reinstatement of intravenous D-amphetamine self- administration. J Neurosci. 1999:19(10):4102-9.

72. Wise RA, Newton P, Leeb K, Burnette B, Pocock P, Justice JB. Fluctuations in nucleus accumbens dopamine concentration during intravenous cocaine self-administration in rats. Psychopharmacology. 1995;120:10-20.

73. Wise RA, Leone P, Rivest R, Leeb K. Elevations of nucleus accumbens dopamine and DOPAC levels during intravenous heroin self-administration. Synapse. 1995;21(2):140-8.

74. Wise RA. Cognitive factors in addiction and nucleus accumbens function: some hints from rodent models. Psychobiology. 1999;27:300-10.

75. Hebb DO. Drives and the C.N.S. (conceptual nervous system). Psychol Rev. 1955;62:243-54.

76. Malmo RB. Activation: a neuropsychological dimension. Psychol Rev. 1959:66:367-86.

77. Wheeler RA, Twining RC, Jones JL, Slater JM, Grigson PS, Carelli RM. Behavioral and electrophysiological indices of negative affect predict cocaine self-administration. Neuron. 2008;57(5):774-85.

78. Wheeler RA, Aragona BJ, Fuhrmann KA, Jones JL, Day JJ, Cacciapaglia F, et al. Cocaine cues drive opposing context-dependent shifts in reward processing and emotional state. Biol Psychiatry. 2011;69(11):1067-74.

79. Wheeler DS, Robble MA, Hebron EM, Dupont MJ, Ebben AL, Wheeler RA. Drug predictive cues activate aversion-sensitive striatal neurons that encode drug seeking. J Neurosci. 2015;35(18):7215-25.

80. Wise RA. Catecholamine theories of reward: a critical review. Brain Res. 1978;152(2):215-47.

81. Fibiger HC. Drugs and reinforcement mechanisms: a critical review of the catecholamine theory. Ann Rev Pharmacol Toxicol. 1978;18:37-56.

82. Wise RA. Dopamine and reward: the anhedonia hypothesis 30 years on. Neurotox Res. 2008;14:169-83.

83. Pickens R, Harris WC. Self-administration of d-amphetamine by rats. Psychopharmacologia. 1968;12:158-63.

84. Crow TJ. A map of the rat mesencephalon for electrical self-stimulation. Brain Res. 1972;36:265-73.

85. Lippa AS, Antelman SM, Fisher AE, Canfield DR. Neurochemical mediation of reward: a significant role for dopamine. Pharmacol Biochem Behav. 1973;1:23-8.

86. Yokel RA, Wise RA. Increased lever pressing for amphetamine after pimozide in rats: implications for a dopamine theory of reward. Science. 1975;187:547-9.

87. Fouriezos G, Wise RA. Pimozide-induced extinction of intracranial selfstimulation: response patterns rule out motor or performance deficits. Brain Res. 1976;103(2):377-80.

88. Wasserman EM, Gomita Y, Gallistel CR. Pimozide blocks reinforcement but not priming from MFB stimulation in the rat. Pharmacol Biochem Behav. 1982;17:783-7.

89. Ettenberg $\mathrm{A}, \mathrm{Camp} \mathrm{CH}$. Haloperidol induces a partial reinforcement extinction effect in rats: implications for a dopamine involvement in food reward. Pharmacol Biochem Behav. 1986;25:813-21.

90. Salamone JD, Cousins MS, Bucher S. Anhedonia or anergia? Effects of haloperidol and nucleus accumbens dopamine depletion on instrumental response selection in a T-maze cost/benefit procedure. Behav Brain Res. 1994;65:221-9.

91. Ikemoto S, Panksepp J. Dissociations between appetitive and consummatory responses by pharmacological manipulations of reward-relevant brain regions. Behav Neurosci. 1996;110(2):331-45. 
92. Wyvell $\mathrm{CL}$, Berridge KC. Intra-accumbens amphetamine increases the conditioned incentive salience of sucrose reward: enhancement of reward "wanting" without enhanced "liking" or response reinforcement. J Neurosci. 2000;20:8122-30.

93. Wise RA. The neurobiology of craving: implications for the understanding and treatment of addiction. J Abnorm Psychol. 1988;97(2):118-32.

94. Di Chiara G, Imperato A. Drugs abused by humans preferentially increase synaptic dopamine concentrations in the mesolimbic system of freely moving rats. PNAS. 1988;85:5274-8.

95. Yokel RA, Wise RA. Attenuation of intravenous amphetamine reinforcement by central dopamine blockade in rats. Psychopharmacology. 1976;48:311-8.

96. de Wit $\mathrm{H}$, Wise RA. Blockade of cocaine reinforcement in rats with the dopamine receptor blocker pimozide, but not with the noradrenergic blockers phentolamine or phenoxybenzamine. Can J Psychol. 1977;31(4):195-203.

97. Roberts DCS, Koob GF, Klonoff P, Fibiger HC. Extinction and recovery of cocaine self-administration following 6-OHDA lesions of the nucleus accumbens. Pharmacol Biochem Behav. 1980;12:781-7.

98. Roberts DCS, Corcoran ME, Fibiger HC. On the role of ascending catecholaminergic systems in intravenous self-administration of cocaine. Pharmacol Biochem Behav. 1977;6:615-20.

99. Kombian SB, Malenka RC. Simultaneous LTP of non-NMDA- and LTD of NMDA-receptor-mediated responses in the nucleus accumbens. Nature. 1994;368:242-6.

100. Nishioku T, Shimazoe T, Yamamoto Y, Nakanishi H, Watanabe S. Expression of long-term potentiation of the striatum in methamphetamine-sensitized rats. Neurosci Lett. 1999;268(2):81-4.

101. Avchalumov Y, Trenet W, Piña-Crespo J, Mandyam C. SCH23390 reduces methamphetamine self-administration and prevents methamphetamine-induced striatal LTD. Int J Mol Sci. 2020;21(18):6491.

102. Ettenberg A, Pettit HO, Bloom FE, Koob GF. Heroin and cocaine intravenous self-administration in rats: mediation by separate neural systems. Psychopharmacology. 1982;78:204-9.

103. Pocock D, Leeb K, Wise RA. Elevations and phasic fluctuations in nucleus accumbens dopamine during IV heroin self-administration. Soc Neurosci Abstr. 1994;20:1234

104. Aghajanian GK, Bunney BS. Dopamine "autoreceptors": pharmacological characterization by microiontophoretic single cell recording studies. Naunyn-Schmiedeberg's Arch Pharmacol. 1977;297(1):1-7.

105. Wise RA. Intravenous drug self-administration: a special case of positive reinforcement. In: Bozarth MA, editor. Methods of assessing the reinforcing properties of abused drugs. New York: Springer-Verlag; 1987. p. 117-41.

106. Bozarth MA, Wise RA. Heroin reward is dependent on a dopaminergic substrate. Life Sci. 1981;29(18):1881-6.

107. Bechara A, Harrington F, Nader K, van der Kooy D. Neurobiology of motivation: Double dissociation of two motivational mechanisms mediating opiate reward in drug-naive versus drug-dependent rats. Behav Neurosci. 1992;106:798-807.

108. Grenhoff J, Aston-Jones G, Svensson TH. Nicotinic effects on the firing pattern of midbrain dopamine neurons. Acta Physiologica Scandanavica. 1986;128:351-8.

109. Doyon WM, Thomas AM, Ostroumov A, Dong Y, Dani JA. Potential substrates for nicotine and alcohol interactions: a focus on the mesocorticolimbic dopamine system. Biochem Pharmacol. 2013;86(8):1181-93.

110. Di Chiara G. Role of dopamine in the behavioural actions of nicotine related to addiction. Eur J Pharmacol. 2000;393:295-314.

111. Corrigall WA, Coen KM. Selective dopamine antagonists reduce nicotine self-administration. Psychopharmacology. 1991;104:171-6.

112. Corrigall WA, Franklin KBJ, Coen KM, Clarke P. The mesolimbic dopaminergic system is implicated in the reinforcing effects of nicotine. Psychopharmacology. 1992;107:285-9.

113. Picciotto MR, Zoli M, Rimondini R, Lena C, Marubio LM, Pich EM, et al. Acetylcholine receptors containing the beta2 subunit are involved in the reinforcing properties of nicotine. Nature. 1998;391(6663):173-7.

114. Maskos U, Molles BE, Pons S, Besson M, Guiard BP, Guilloux JP, et al. Nicotine reinforcement and cognition restored by targeted expression of nicotinic receptors. Nature. 2005;436(7047):103-7.
115. Tolu S, Eddine R, Marti F, David V, Graupner M, Pons S, et al. Co-activation of VTA DA and GABA neurons mediates nicotine reinforcement. Mol Psychiat. 2013;18(3):382-93.

116. Acquas E, Carboni E, Leone P, Di Chiara G. SCH 23390 blocks drugconditioned place-preference and place-aversion: anhedonia (lack of reward) or apathy (lack of motivation) after dopamine-receptor blockade? Psychopharmacology. 1989;99(2):151-5.

117. Huang YY, Kandel DB, Kandel ER, Levine A. Nicotine primes the effect of cocaine on the induction of LTP in the amygdala. Neuropharmacology. 2013;74:126-34.

118. Chen YH, Hsieh TH, Kuo TT, Kao JH, Ma KH, Huang EY, et al. Release parameters during progressive degeneration of dopamine neurons in a mouse model reveal earlier impairment of spontaneous than forced behaviors. J Neurochem. 2019;150(1):56-73.

119. Swanson LW, Petrovich GD. What is the amygdala? Trends Neurosci. 1998;21(8):323-31.

120. Wise RA. Maximization of ethanol intake in the rat. Advances in Exper Med Biol. 1975;59:279-94

121. Wise RA. Voluntary ethanol intake in rats following exposure to ethanol on various schedules. Psychopharmacologia. 1973;29(3):203-10.

122. Samson HH. Initiation of ethanol reinforcement using a sucrose-substitution procedure in food- and water-sated rats. Alcohol Clin Exper Res. 1986;10:436-42.

123. Sinclair JD, Hyytiä $P$, Nurmi M. The limited access paradigm: description of one method. Alcohol (Fayetteville, NY). 1992;9(5):441-4.

124. Simms JA, Steensland P, Medina B, Abernathy KE, Chandler LJ, Wise $\mathrm{R}$, et al. Intermittent access to $20 \%$ ethanol induces high ethanol consumption in Long-Evans and Wistar rats. Alcohol Clin Exper Res. 2008;32(10):1816-23.

125. Goldstein DB, Pal N. Alcohol dependence produced in mice by inhalation of ethanol: grading the withdrawal reaction. Science. 1971;172:288-90.

126. Macey DJ, Schulteis G, Heinrichs SC, Koob GF. Time-dependent quantifiable withdrawal from ethanol in the rat: effect of method of dependence induction. Alcohol (Fayetteville, NY). 1996;13(2):163-70.

127. Hopf FW, Martin M, Chen BT, Bowers MS, Mohamedi MM, Bonci A. Withdrawal from intermittent ethanol exposure increases probability of burst firing in VTA neurons in vitro. J Neurophysiol. 2007;98(4):2297-310.

128. Doyon WM, Ostroumov A, Ontiveros T, Gonzales RA, Dani JA. Ethanol produces multiple electrophysiological effects on ventral tegmental area neurons in freely moving rats. Addiction Biol. 2021;26(2):e12899.

129. Brodie MS, Shefner SA, Dunwiddie TV. Ethanol increases the firing rate of dopamine neurons of the rat ventral tegmental area in vitro. Brain Res. 1990;508(1):65-9.

130. Rassnick S, Pulvirenti L, Koob GF. Oral ethanol self-administration in rats is reduced by the administration of dopamine and glutamate receptor antagonists into the nucleus accumbens. Psychopharmacology. 1992;109:92-8.

131. Samson HH, Hodge CW, Tolliver GA, Haraguchi M. Effect of dopamine agonists and antagonists on ethanol-reinforced behavior: the involvement of the nucleus accumbens. Brain Res Bull. 1993;30:133-41.

132. Ting AKR, Dockstader C, Heinmiller A, Grieder T, van der Kooy D. GABA(A) receptors mediate the opposing roles of dopamine and the tegmental pedunculopontine nucleus in the motivational effects of ethanol. Eur J Neurosci. 2009;29(6):1235-44.

133. Laviolette SR, van der Kooy D. GABA(A) receptors in the ventral tegmental area control bidirectional reward signalling between dopaminergic and non-dopaminergic neural motivational systems. Eur J Neurosci. 2001;13(5):1009-15.

134. Tanda G, Pontieri FE, Di Chiara G. Cannabinoid and heroin activataion of mesolimbic dopamine ransmission by a common $\mu_{1}$ opioid receptor mechanism. Science. 1997:276:2048-50.

135. Justinova Z, Tanda G, Redhi GH, Goldberg SR. Self-administration of delta9-tetrahydrocannabinol (THC) by drug naive squirrel monkeys. Psychopharmacology. 2003;169(2):135-40.

136. Chen JP, Paredes W, Li J, Smith D, Lowinson J, Gardner EL. Delta 9-tetrahydrocannabinol produces naloxone-blockable enhancement of presynaptic basal dopamine efflux in nucleus accumbens of conscious, freely-moving rats as measured by intracerebral microdialysis. Psychopharmacology. 1990;102(2):156-62. 
137. Lupica CR, Riegel AC. Endocannabinoid release from midbrain dopamine neurons: a potential substrate for cannabinoid receptor antagonist treatment of addiction. Neuropharmacology. 2005;48(8):1105-16.

138. Oleson EB, Cachope R, Fitoussi A, Tsutsui K, Wu S, Gallegos JA, et al. Cannabinoid receptor activation shifts temporally engendered patterns of dopamine release. Neuropsychopharmacology. 2014;39(6):1441-52.

139. Bossong MG, van Berckel BN, Boellaard R, Zuurman L, Schuit RC, Windhorst $A D$, et al. Delta 9-tetrahydrocannabinol induces dopamine release in the human striatum. Neuropsychopharmacology. 2009;34(3):759-66.

140. Mansbach RS, Nicholson KL, Martin BR, Balster RL. Failure of Delta(9)tetrahydrocannabinol and CP 55,940 to maintain intravenous selfadministration under a fixed-interval schedule in rhesus monkeys. Behav Pharmacol. 1994;5(2):219-25.

141. Wakeford AGP, Wetzell BB, Pomfrey RL, Clasen MM, Taylor WW, Hempel $B J$, et al. The effects of cannabidiol (CBD) on $\Delta^{9}$-tetrahydrocannabinol (THC) self-administration in male and female Long-Evans rats. Exper Clin Psychopharmacol. 2017;25(4):242-8.

142. Freels TG, Baxter-Potter LN, Lugo JM, Glodosky NC, Wright HR, Baglot $S L$, et al. Vaporized cannabis extracts have reinforcing properties and support conditioned drug-seeking behavior in rats. J Neurosci. 2020;40(9):1897-908.

143. Smoker MP, Mackie K, Lapish CC, Boehm SL 2nd. Self-administration of edible $\triangle(9)$-tetrahydrocannabinol and associated behavioral effects in mice. Drug Alcohol Depend. 2019;199:106-15.

144. Jordan CJ, Xi ZX. Progress in brain cannabinoid CB(2) receptor research: from genes to behavior. Neurosci Biobehav Rev. 2019;98:208-20.

145. Mateo Y, Johnson KA, Covey DP, Atwood BK, Wang HL, Zhang S, et al. Endocannabinoid actions on cortical terminals orchestrate local modulation of dopamine release in the nucleus accumbens. Neuron. 2017;96(5):1112-26.e5.

146. Davis MI, Crittenden JR, Feng AY, Kupferschmidt DA, Naydenov A, Stella $\mathrm{N}$, et al. The cannabinoid-1 receptor is abundantly expressed in striatal striosomes and striosome-dendron bouquets of the substantia nigra. PLoS ONE. 2018;13(2):e0191436.

147. Zangen A, Solinas M, Ikemoto S, Goldberg SR, Wise RA. Two brain sites for cannabinoid reward. J Neurosci. 2006;26(18):4901-7.

148. Deneau G, Yanagita T, Seevers MH. Self-administration of psychoactive substances by the monkey. Psychopharmacologia. 1969;16:30-48.

149. Pickens R, Muchow D, DeNoble V. Methohexital-reinforced responding in rats: effects of fixed ratio size and injection dose. J Pharmacol Exp Ther. 1981;216(2):205-9.

150. Griffiths RR, Lukas SE, Bradford LE, Brady JV, Snell JD. Self-injection of barbiturates and benzodiazepines in baboons. Psychopharmacology. 1981;75:101-9.

151. Szostak C, Finlay JM, Fibiger HC. Intravenous self-administration of the short-acting benzodiazepine midazolam in the rat. Neuropharmacology. 1987;26:1673-6.

152. Ikemoto $S, K$ Kohl RR, McBride WJ. GABA(A) receptor blockade in the anterior ventral tegmental area increases extracellular levels of dopamine in the nucleus accumbens of rats. J Neurochem. 1997;69:137-43.

153. Ikemoto S, Murphy JM, McBride WJ. Regional differences within the rat ventral tegmental area for muscimol self-infusions. Pharmacol Biochem Behav. 1998;61:87-92.

154. Heikkinen AE, Möykkynen TP, Korpi ER. Long-lasting modulation of glutamatergic transmission in VTA dopamine neurons after a single dose of benzodiazepine agonists. Neuropsychopharmacology. 2009:34(2):290-8.

155. Tan KR, Brown M, Labouèbe G, Yvon C, Creton C, Fritschy JM, et al. Neural bases for addictive properties of benzodiazepines. Nature. 2010;463(7282):769-74.

156. Soden ME, Chung AS, Cuevas B, Resnick JM, Awatramani R, Zweifel LS. Anatomic resolution of neurotransmitter-specific projections to the VTA reveals diversity of GABAergic inputs. Nat Neurosci. 2020;23:968.

157. Vashchinkina E, Panhelainen A, Aitta-Aho T, Korpi ER. GABAA receptor drugs and neuronal plasticity in reward and aversion: focus on the ventral tegmental area. Front Pharmacol. 2014;5:256.

158. Di Chiara G, Imperato A. Preferential stimulation of dopamine release in the nucleus accumbens by opiates, alcohol, and barbiturates: studies with transcerebral dialysis in freely moving rats. Ann NY Acad Sci. 1986;473:367-81.
159. O'Brien DP, White FJ. Inhibition of non-dopamine cells in the ventral tegmental area by benzodiazepines: relationship to A10 dopamine cell activity. Eur J Pharmacol. 1987;142:343-54.

160. Schelp SA, Brodnik ZD, Rakowski DR, Pultorak KJ, Sambells AT, Espana RA, et al. Diazepam concurrently increases the frequency and decreases the amplitude of transient dopamine release events in the nucleus accumbens. J Pharmacol Exp Ther. 2018;364(1):145-55.

161. van der Kooij MA, Hollis F, Lozano L, Zalachoras I, Abad S, Zanoletti $\mathrm{O}$, et al. Diazepam actions in the VTA enhance social dominance and mitochondrial function in the nucleus accumbens by activation of dopamine D1 receptors. Mol Psychiatry. 2018;23(3):569-78.

162. Horger BA, Wellman PJ, Morien A, Davies BT, Schenk S. Caffeine exposure sensitizes rats to the reinforcing effects of cocaine. NeuroReport. 1991;2:53-6.

163. Bradley CA, Palmatier MI. Intravenous and oral caffeine self-administration in rats. Drug Alcohol Depend. 2019;203:72-82.

164. Myers KP, Izbicki EV. Reinforcing and aversive effects of caffeine measured by flavor preference conditioning in caffeine-naive and caffeineacclimated rats. Physiol Behav. 2006;88(4-5):585-96.

165. Yee M, Maal-Bared G, Ting AKR, Chwalek M, Mackay-Clackett I, Bergamini $M$, et al. Segregation of caffeine reward and aversion in the rat nucleus accumbens shell versus core. Eur J Neurosci. 2020;52(3):3074-86

166. Galvalisi M, Prieto JP, Martinez M, Abin-Carriquiry JA, Scorza C. Caffeine induces a stimulant effect and increases dopamine release in the nucleus accumbens shell through the pulmonary inhalation route of administration in rats. Neurotox Res. 2017;31(1):90-8.

167. Volkow ND, Wang GJ, Logan J, Alexoff D, Fowler JS, Thanos PK, et al. Caffeine increases striatal dopamine D2/D3 receptor availability in the human brain. Trans Psychiat. 2015;5:e549.

168. Zheng $X$, Takatsu S, Wang H, Hasegawa H. Acute intraperitoneal injection of caffeine improves endurance exercise performance in association with increasing brain dopamine release during exercise. Pharmacol Biochem Behav. 2014;122:136-43.

169. Holstein SE, Barkell GA, Young MR. Caffeine increases alcohol selfadministration, an effect that is independent of dopamine $D(2)$ receptor function. Alcohol (Fayetteville, NY). 2021;91:61-73.

\section{Publisher's Note}

Springer Nature remains neutral with regard to jurisdictional claims in published maps and institutional affiliations.

Ready to submit your research? Choose BMC and benefit from

- fast, convenient online submission

- thorough peer review by experienced researchers in your field

- rapid publication on acceptance

- support for research data, including large and complex data types

- gold Open Access which fosters wider collaboration and increased citations

- maximum visibility for your research: over $100 \mathrm{M}$ website views per year

At BMC, research is always in progress.

Learn more biomedcentral.com/submissions 